\title{
THE ROLE OF LAW IN CREATING COMMITMENT
}

\section{Mohammad Reza Komeili Fard ${ }^{1}$ \\ Ehsan Ali Akbari Babookani²}

\begin{abstract}
In article 1991 of French civil law, the laws such as contract and other sources of commitment are one of the commitment sources. Some of the French lawyers consider law as the source of all commitments and believe that: other sources get their credit from law, but the law is committed to two types of sources: direct and indirect and also legal commitment is in two cases: negative commitments and positive commitments. The legislator in negative commitment tries more, due to being comfortable and less annoying. In this article observing the law source, the examples and the effects in Iran law are focused.
\end{abstract}

Keywords: Law, Negative Commitments, Positive Commitments

\section{Definition and commitment arising from the law}

Canon is Arabic form of law and it is having many different meanings such as: Tradition, order, scale, question and a vehicle to set lines. After a while the meaning that is accepted in science is used. It means: the law is key criterion that is in accordance with individuals and the verdict of all them is known from the mentioned criterion. Such term is also used in credit affairs such as Statute book and also in the case of real affairs such as: mathematics, nature, etc. accordingly, the law is divided in to two branches of natural and postural, but here postural law is considered. In defining postural law, it could be asserted that: the law is general principal that is accepted as the regulator of social relations on behalf of governing board and community members and also

\footnotetext{
${ }^{1}$ Phd candidate, Department of Fiqh and Law, Najaf Abad Branch, Islamic Azad University, Najaf Abad, Iran. Email: e.aliakbari@ahl.ui.ac.ir

${ }^{2}$ Assistant professor, Department of Fiqh and Law, University of Isfahan, Isfahan, Iran.

Email: e.aliakbari@ahl.ui.ac.ir
} 
enforcement guarantee is available. In case of lacking enforcement guarantee on behalf of nation or government, a legal rule is law, but in fact considering law for that isn't applicable (Gorji 1996:273, a number of authors 1989:292)

Defining law is different from law scholar's point of view. Some people consider national acceptability as statutory requirement of a rule and the others consider such role to manage the government. As some people consider all social regulations, administrative verdicts and governmental legislation as law and the others consider some parts of the rules that has been approved generally and continually as law and consider the rest as acts and administrative affairs.(Jafari Langerodi 1999:95)so common issues that is required in a legal article from all lawyers view are: issue generalization to adjust social relation and also having enforcement guarantee as special verdicts that are issued for special individual isn ` $t$ considered as law, even that verdict is mentioned in Quran. The rules which aren't related to social connections and is usable only as a duty such as: All obligatory prayers and also ethical issues, recommended actions and detestable which are existing in Islam or legal requirements and customs which aren't mentioned in Islam. (A number of authors 1989; 293)

The law is divided in to two categorizations from necessity level point of view. The first type of the law is imperative rules. it means: the law which people`s willing to oppose is ineffective. The content of this law is anchored with public order, good behavior and maintaining the interest of the parties. For example: the obligations related to charity or providing trustee and the guardian for the individuals. The second type of law is complimentary. Sometimes the individuals could perform against law requirement. Even though the law is obligatory in some cases, but these cases are the successor of individual's silence. For example the parties could abort them totally in option topic. (Katozain 1998; 186/1, Jafari Langroodi, 1990; 96)

From the view of the commitment derived from the law, just imperatives laws are considered, as complimentary laws as their names show complete other sources of commitment and don`t create commitment themselves. In dividing the tools and sources of commitment, the law is 
considered as one of the sources of commitment, in range of contract, sub contract, crime and sub-crime.

How the law is direct source of commitment and obligation? The source of any commitment is law. It means: public trend that arranges legal connections based on the interest of the society. Commitment sources such as contract, sub-contract, crime and subcrime get their power and credit from the law.

Even contract that seems independent from law is following the will of the parties (Shahvari, 1975; 590/3). For example: article 219: the contracts which are based on law are enforced between dealers and their surrogates and article 968 that require: the commitment derived from contract is following contract event law and article 975 that asserts: private contracts that are in contrast with public order wouldn`t be applicable and also article 10 of civil law that considers the contracts which aren't against the law. Therefore the legislator guaranteed the implementation of contract provisions for economic and financial order in the society and also free will due to public interest, so it is respectable to where public order isn't damaged. (Katozain 2006; 90)
Therefore, it is law that commitments are derived from and the law elaborates the verdicts. It must be mentioned that: law is the source of commitments in two ways: sometimes indirectly and due o the act of human and sometimes directly and without the interruption of human acts (Jafari Langerodi, 1999;121) what considering there is the commitment that is derived from law directly, not through median.

Pelniol divided the commitment derived from law in to two groups: first type is when law forces somebody to do something directly to prevent the damage to the others and another type is when obligation is to remove harm that is gained through law violation. He considers the law as the source of subcontract, crime and sub-crime and is created to compensate the damages which are made due to violation from legal obligations. Here the individual ignored legal duty, so the law considers law as the origin of all obligations out of contract and considers the basis of all duties to eliminate the future damages and also the damages which are made unfair. (Katozain 2007; 96)

The commitments due to contract, sub-contract, crime and subcrime are having direct source from them 
while volition is involved and law made their basis indirectly and identifies the term to create commitment formerly. Therefore, the source of buyer and seller commitment in the framework that is specified by law is the contract and the law is indirect source. In the case that somebody performs something improperly and harms the others, should compensate that. As result the direct source to compensate loss is the mentioned forbidden action and also indirect source law.

The article 220 of civil law asserted that: the contract obliges the parties to implement what is mentioned in and also all results that are gained through custom or law from the contract. In this article all commitment derived from the contract is separated from commitment derived from law.

Whenever one of the sources and commitment tools is created, there would be no difference between the commitments that are created in different status. For example: contract that is source of commitment, either selling or rent, etc. for each of them, specific commitment isn't identified and all of them are under the title of contract and commitment derived from contract. All of the statuses are the same or all status of sub-crime creates damage to the others and the commitments are the same, but in law as commitment source, there are different status and not similar one, so the law identified specified commitments and in each case, a legal task or material action is utilized. There specific status such as direct source of specific commitment isn`t created and for each one, the source isn't identified. Each of them creates specific commitment and the law is the source of such commitment, as the law set them, not through basic text, but through specific way that identifies the status and the scope. And also identifies the verdict through law not contract or crime and sub-crime (Shahvari. 1975:598/3)

The status that law is the source in just creates commitment when the law occurs and creates no commitment out of law. It means when this status is eliminated from law, wouldn't be acceptable to implement.

The statuses which are specified by the law sometimes are materialist or legal. Any of them identifies legal commitment with direct source of law. Material events like family, commitments, neighborhood commitments and legal implementation are the cases related to individual desire 
such as requirement warrant. So to identify direct commitment derived from law, there is no way, but through law. Law text is a tool that is in charge of identifying legal commitment basis and asserting the verdicts and terms. It means: there is no other tools to acquire legal commitment and acute determination of them. When there is a text, a commitment would be available, so there would be legal commitment (Najm Jobran, 1987; 337)

Maybe it seems that legal commitments are depending on legal texts and such texts and legal articles create such commitments forcefully without existing predetermined method in creating such commitment. When the law appreciates the creation of legal commitment, this commitment would be created in accordance with legal text. The truth is that legislator is following some natural traditions in creating legal commitment consciously or nonconsciously, like following the other legal relations. Legal commitment is based on two reasons. First legal commitments which are based on material reasons and legal commitments which are based on individual will. Shahvari1975:600/3)
Legal material commitments are two types: positive commitments and negative commitments.

Negative commitments: the human beings are obliged to follow rules on their own based on the law. As result, voluntary commitment needs no justification and explanation. When there is commitment not based on volition, the law is the only tool to create that .The law enters social and literary basis in creating involuntary commitment, but it couldn't rely on such credits, but it should consider other credits and basis in legal structure. The most important one is that: law can't implement vague commitment. For example: the law can`t set positive commitment and force everyone to help the others .such clear commitments are remained in the scope of society and literature fields and the law focuses on them with tolerance and also changes some to legal commitments. In this case it moves from ethic and society world to law world. The first step that could be done by the law is in the field of negative commitment, as such commitments are easier to determine (Najm Jobran, 1987; 334, Shahvari 1975; 605/3)

When the law moves from negative scope and ignorance of damage 
to help, the limits would be mixed and the rules would be dumb.

Positive commitments: sometimes the law moves from positive commitment, but by high foresight. For example: the law can't assert generally to help the others, but it should be mentioned: help the others, but in specified limit. For example: helping the others is specified in family framework or the individuals who have close relation with the others, or in neighbor scope, or in society , as united society, some commitments are obligatory towards government. In family framework, different commitment would be created such as: Marital obligations and commitments between parents and children, alimony payments and the other types and all of these commitments are based on solidarity between the members. In neighbor framework also there would be different commitments such as: Avoidance of harm to neighbors, respect and not mastering the neighbors from specified distance or the commitments which are latent due to having common wall (Shahvari,1975:664/3T Najm Jabran 1987:340)

Also the law considered some commitments on behalf of job owner towards the employers. Also in society scope, the law considered the commitments on behalf of individuals against the government and the most important one is paying tax. Therefore the law is moving with solidarity in all mentioned parts. The law creates no commitment but based on social basis.

Legal commitments which are based on individual volition:

As it is asserted before; the contract is the origin of commitments, but could unilateral commitments create commitment and is it the origin of commitments?

There is no doubt that unilateral commitments have different legal results. The French believe that: the commitment that is originated from legal act is just a contract but unilateral commitments wouldn't create commitment independently, except by law prescription. But in laws of Switzerland and Germany, individual volition could be considered as commitment source. Sigel one of the German lawyers believe that: whoever who enters the contract, is just obliged on its own, not by the agreement of volition with the others volition and due to this truth, exigency creates commitment and the individual can't ignore that. Some of 
the other German lawyers believe that: there is no ban in legal law that obliges them on their own volition. The human being is having freedom, of course in a limit that law permitted. There the power of volition is stronger than two volition agreement theory, as individual volition is enough to create obligation and this is the final part of volition power level. The fan of this theory believes that: individual volition theory isn't based on proper basis, as debtor would lead to individual volition, but it isn't clear how the creditor would be committed without any request? Also if one way volition could create commitment, could cancel that. Therefore the commitment and obligation of committed person depends on his volition. As result the commitment would be void. (Najm Jobran,1987;342, Shahvari,1975;670/3)

By such commentaries, unilateral commitments in Iran law and jurisprudence is considered as independent source in creating commitment(Katozain 1997;92) and also contract is having minor role ,but in French laws, the laws which are created by individual volition is legal commitment with direct source of law. As we mentioned the basis of legal commitment is legal article. Legal article is the lonely tools that creates legal commitment and is considered as direct source of commitment and legal article determines the basis of this commitment, as we presented some types of legal commitments. Generally, it could be mentioned that: legal commitments like the other commitments create through concession, action or refusal of work. The commitment to pay alimony, tax and labor accidents are among concession ways. The commitment in neighbor affairs to do something is among obligation cases and neighbor commitment not to harm the neighbors is among commitment to refuse work cases ( Shahvari,1975:677/3). It isn't necessary that legal article be available in civil law, as criminal laws and the other laws guarantee the articles which create legal commitments and such articles identify the basis of commitment and verdicts. For example: commitment to pay tax originates from verdicts and basis would be tax laws.

\section{Instances}

The law commandments and prohibitions are following interests and corruptions. The commandment that leads to corruption would be prohibited 
and also the commandment that leads to benefaction would be assigned, but law isn't authorized in assessing interests and corruptions and also creating obligations and prohibitions. There is no doubt that social interest requires the individuals to be collaborator, but sympathy and complicity is an absolute term and also non-limited and also law can`t determine a rule for, so refer aspect would be ignored inevitably and also would persuade itself with instances which could be arranged.

In French law, some instances of commitment are mentioned derived from law in article 1370 of civil law and assert: the obligations would be achieved without any contract on behalf of someone or on the behalf of a person the commitment is accepted towards him. Some of such commitment is gained through law and some of them are gained through individual actions. The first group is the obligations which are gained involuntarily, such as: the obligations between neighbors, parent's obligations and other individuals who can't ignore their duty. Therefore the commitments derived from law are out of volition range and directly derived from law such as:

\section{1- Individual duty to pay} alimony to relatives.

In ninth book of civil law paying alimony is discussed and also rules related to women alimony which is sub-branch of marriage commitments and it is also through the commitments of law. The goal of law is to guarantee correlation between family members and moral duty related to help the relatives is located in this scope. In defining the obligation to help the others, it is told: legal commitment available among close families and due to this fact, each rich person is responsible to afford some poor people.(Katozian ;1996;419)therefore , the duty of close relatives to help each other isn't just moral task to do, but legal obligation that could be asked by the court . Therefore governing grammar is different from the commitment to pay the alimony derived from marriage and is having special verdicts. For example; in obliging to help the relatives, two main factors should be collected: the first factor is kinship and second factor is financial affordability and others need to help.

The article 1196 of civil law asserts that: in the relation among the relatives, they are obliged to help each other, whether vertical or horizontal and 


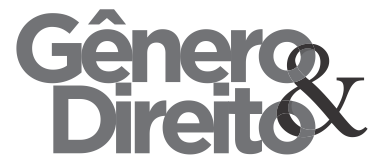

Periódico do Núcleo de Estudos e Pesquisas sobre Gênero e Direito

Centro de Ciências Jurídicas - Universidade Federal da Paraíba V. 8 - $\mathrm{N}^{\circ} 02$ - Ano 2019 - Special Edition

ISSN | 2179-7137 | http://periodicos.ufpb.br/ojs2/index.php/ged/index other articles (article 1197 on) would be asserted other terms. In French laws, in spite of relationship between father and mother and also spouse, the obligation to help is available while marriage remains. (Articles 206 and 207 civil law).

Of course in France, marriage is kind of private law. It means: type of Conditional and forced contract and their volition is just limited to acceptance of the frame that legislator imposed and the parties can`t change that. As the parties get married, they should follow some rules that legislator imposed. (Mazo,1996;402/2).

In Swiss law (article328 of Swiss commitment laws) sisters and brothers are considered as relatives who are committed to help. Another case of obliging to help by the law is related to children under supervision of the families who are selected to be supervised in the families and are considered as the children of the family. The article 11 of supporting unsupervised children says: the duty of the supervisor and under supervision children is educating, paying alimony, respecting such as parents and children relation.

\section{2- Inheritance}

Another instance of commitment derived from law is inheritance. None of the testator and inherit could cause any change in their share, till the time it is transferred to the family according to agreed rules. (Shahidi 2000) so the legislator gave some commitment on inherits. According to article 829 of Civil law, inherit is committed to claim for the laws and debts which are related to decedent, before property division.

\section{3-the commitment of the owner to observe neighbor rights and respect easement rights}

According to article 30 of civil law, each owner could capture his property anyway, but this rule is limited to maintain order and observe justice. Due to this fact in article 132 of civil law related to neighbor's relation, it is asserted that no one could occupy his property by harming the neighbors, excepting the case that no harm would be executed. Therefore the neighbors are having some obligatory commitments against the others. For example: article 109 of Civil law and Apartment ownership law. A limitation related to property vicinity is type of easement type 
and this law is derived from law and it could be positive or negative. For example: the owner prohibition to open door or window in his wall is type of negative easement right and negative commitment and is to benefit neighbors.(Katozain1999:113)

Protection of property rights in article 136 of Civil law, right to dig aqueducts and also well construction right are types of easement right and is specified by law and caused commitment for both parties.

\section{4-the commitments of condominium against each other}

The common law commitment and multiple owners lead the owner not to do proper occupation on his property and some commitments would be imposed on him. One of the commitments in article 808 of civil law is about obtaining Survivorship that the owner has to observe the rights of the neighbor and sell the property by his satisfaction. It means there would be negative commitment to not sell the share part to the others. Sometimes law forces some commitments to the individuals to protect discipline and also to utilize the estates and in some cases uses special rules to use them, such as: Price stability to ban hoarding about general objects, requirement to record events as marriage, divorce, birth and death rituals exploitation of mines, oil nationalization, the obligation to sell the lands near railway, roads, water and gas ducts etc. Prohibit the importation of certain goods into the country, the laws of the land acquisition, rehabilitation and urban development, the laws relating to land reforms, preservation of national monuments and cultural heritage, and more.

\section{5- Land regeneration and hunt ban}

In such cases, except the cases which are determined by the individual, some commitments are specified for them, such as: article 145 of civil law that asserts: the generator should observe other laws related to this topic such as : urban land law observance. Also article 147 of civil law is about the fact when somebody gets permissible property would be the owner. Therefore the individual should observe the commitments justified by law. Also articles 162 and 171 would be considered. 
6- Parents commitment to observe and protect children

Province in family relation is kind of power that legislator uses to manage Financial and sometimes raising children.(article 1183 of civil law) and parents power source is directly law and presenting this post is not related to individuals control. Due to this fact father and parental family are called Coercive parents and no one is authorized to change province. As a child is born, he would be under supervision of his parents. Also coercive parents isn't authorized agree on property division that parents are having share directly and out of court. (Article 313 of civil law) guardian should also observe the rules. Article 1217 of civil law considers other commitments in article 1235 in civil law as the duties of the guardian.

\section{8- Parents commitment to the preservation and education of children}

Article 1168 of civil law that is about the relation of parents and children considers social interests and everything is duty, so authorization of parents is to protect children and due to this fact, it is related to public discipline and also the legislator considers commitments on them. Protection in public term involves all tasks to supervise children, such as Equipment maintenance, proper housing and living and prevent harm to children and avoid hazardous work.

Except protection, raising the children is on parents too (article 1178 of civil law) the parents should make the children aware of social life and supervise their behavior and treatment continuously and also teach relational and national traditions (Katozain, 2009;380)

The depositary obligations to observe affairs related to the properties of missing person

The depositary that is chosen to manage the properties of missing person would have some commitments to observe (article 1015 civil law)

\section{9-Troth commiment in the event of a} collapse in union

According to article 1037 of civil law any of the troth in case of collapsing the union should ask for the gifts and another party should pay the same or similar.

Commitment to pay tax 


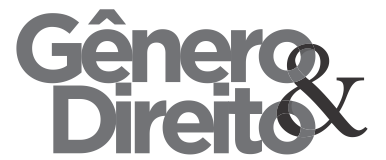

Periódico do Núcleo de Estudos e Pesquisas sobre Gênero e Direito

Centro de Ciências Jurídicas - Universidade Federal da Paraíba V. 8 - No 02 - Ano 2019 - Special Edition

ISSN | 2179-7137 | http://periodicos.ufpb.br/ojs2/index.php/ged/index
Article 1 of direct taxes asserts that: following people should pay tax:1all owners of estates such as natural or legal persons to the properties in Iran.2 any natural Iranian resident to all incomes on education in or outside of the country.3-any Iranian legal person to the income on education in Iran.4-any Iranian legal person to all income to all incomes on education in or outside of the country, so tax law is committed to pay tax for specific people that is derived from tax law.

\section{References}

Langroodi, MJ, (1999), rights and obligations, $\mathrm{ch} 3$, Treasure of Knowledge Publications, Tehran

Langroodi, MJ, (1990), Introduction to the Science of Law, ch 2, The Treasure of Knowledge, Tehran

Langroodi, MJ, (1999), extended Drtrmynvlvzhy law, no one, Treasure of Knowledge Publications, Tehran

Langroodi, MJ, (1961), Tasyraradh civil law, ch 1, Tehran
Langroodi, MJ, (2001), Philosophy of

Rights, ch 1, The Treasure of Knowledge, Tehran

Azmvlfyn Mass (1368), An Introduction to Islamic rights, no one, side, Tehran Shahidi, M., (1989), Inheritance, No 3, publisher, Tehran

Katozian, N., (2007), Out Azqrardad obligations, (g) 7, Tehran University Press

Katozian, N., (1997), Qvadmvmy Contracts, No 4, equity release, Tehran

Katozian, N., (1998), Philosophy of Law, ch 1, equity release, Tehran

Katozian, N., (2006), the general theory of obligations, g 3, Nshrmyzan, Tehran Katozian, N., (1996), Family Law, ch 1, Nshrylda, Tehran

Katozian, N., (1998), unilateral obligations, g 2, Nshrdadgstr, Tehran

Consistory, N., (1999), property ownership, g 2, Nshrdadgstr, Tehran

Georgian, A., (2008), Principles of Islamic Law, ch 1, Nshrmyzan, Tehran 
Georgian, A., (1993), Legal

Proceedings, vol 1 and 2, Tehran

University

Snhvry, Abdul (1975), Alvsyt on civil Alqanvn description, Daralahya'altras Arabiya, Egypt

Snhvry, Abdul (1980), Msadralhq on Islamic Alfqhy, Daralahya'altras Arabiya, Egypt

Najam compensation, Joseph, (1987), Alnzryh Alamh Llmvjbat Court Aljamyh printing, Beirut, N., (1999), property ownership, g 2, Nshrdadgstr, Tehran

Georgian, A., (2008), Principles of Islamic Law, ch 1, Nshrmyzan, Tehran

Georgian, A., (1993), Legal Proceedings, vol 1 and 2, Tehran University

Snhvry, Abdul (1975), Alvsyt on civil Alqanvn description, Daralahya'altras Arabiya, Egypt

Snhvry, Abdul (1980), Msadralhq on Islamic Alfqhy, Daralahya'altras Arabiya, Egypt
Najam compensation, Joseph, (1987), Alnzryh Alamh Llmvjbat Court Aljamyh printing, Beirut

Mazeaud(henri.leonet,jean),(1996).leco ns de droit civil francais.2ed.paris 